\title{
The Evolution of Personal Wealth in the Former Soviet Union and Central and Eastern Europe
}

\author{
Sergei Guriev ${ }^{1}$ and Andrei Rachinsky ${ }^{2}$
}

October 2006

\begin{abstract}
This study discusses the evolution of personal wealth in transition economies. While data availability is still a problem, the available indirect evidence suggests privatization has resulted in an increase in personal wealth but also in personal wealth inequality, especially in the countries that lagged behind in building effective institutions. Another source of wealth inequality is the high income inequality due to wage decompression coupled with the low saving rates among the poor. We pay a special attention to one of the most noticeable implications of this rise in personal wealth and wealth inequalitythe emergence of so called 'oligarchs'. Using the comprehensive dataset of Muscovites' incomes we show that surveys that do not take into account the first- and second-tier rich (billionaires and millionaires) may drastically underestimate inequality.
\end{abstract}

Keywords: inequality, wealth distribution, oligarchs, privatization JEL classification: D31, O52, P36

Copyright @ C UNU-WIDER 2006

${ }^{1}$ New Economic School, CEFIR, and CEPR, email: sguriev@nes.ru; ${ }^{2}$ Center for Economic and Financial Research (CEFIR) at the New Economic School, email: arachinsky@cefir.ru

This study has been prepared within the UNU-WIDER project on Personal Assets from a Global Perspective, directed by Jim Davies.

UNU-WIDER acknowledges with thanks the financial contributions to its research programme by the governments of Denmark (Royal Ministry of Foreign Affairs), Finland (Ministry for Foreign Affairs), Norway (Royal Ministry of Foreign Affairs), Sweden (Swedish International Development Cooperation Agency_Sida) and the United Kingdom (Department for International Development). 


\section{Acknowledgements}

This paper builds substantially on Guriev and Rachinsky (2005) and Guriev and Megginson (2006). The authors are grateful to Jim Davies, Patrick Honohan, Branko Milanovic, Tony Shorrocks, and Ruslan Yemtsov, and to the WIDER conference participants for insightful comments.

The World Institute for Development Economics Research (WIDER) was established by the United Nations University (UNU) as its first research and training centre and started work in Helsinki, Finland in 1985. The Institute undertakes applied research and policy analysis on structural changes affecting the developing and transitional economies, provides a forum for the advocacy of policies leading to robust, equitable and environmentally sustainable growth, and promotes capacity strengthening and training in the field of economic and social policy making. Work is carried out by staff researchers and visiting scholars in Helsinki and through networks of collaborating scholars and institutions around the world. www.wider.unu.edu publications@wider.unu.edu

UNU World Institute for Development Economics Research (UNU-WIDER)

Katajanokanlaituri 6 B, 00160 Helsinki, Finland

Camera-ready typescript prepared by Lorraine Telfer-Taivainen at UNU-WIDER

The views expressed in this publication are those of the author(s). Publication does not imply endorsement by the Institute or the United Nations University, nor by the programme/project sponsors, of any of the views expressed. 


\section{Introduction}

Transition from plan to market is a natural experiment of historical significance. It has affected economic relationships, social and political structures and, what is most important, the lives of 1.5 billion people in almost 30 countries. While the transformational recession, subsequent recovery and other aggregate processes have been studied extensively, our understanding of the evolution of personal wealth and of the distributional effects of transition is still far from complete. This is not because these issues are unimportant. Transition countries are, on average, rather wealthy. Figure 1 and Table 1 show the standing of transition countries in terms of wealth with regard to other economies comparable per capita GDP. 1 Unlike the pre-transition years, much of this wealth is now owned by individuals. Privatization has provided many citizens of transition countries with property rights for assets they were de facto controlling and using during the communist era.

Figure 1: Transition countries are on average richer than other countries with comparable per capita income

Log (Aggregate wealth / Annual GDP)

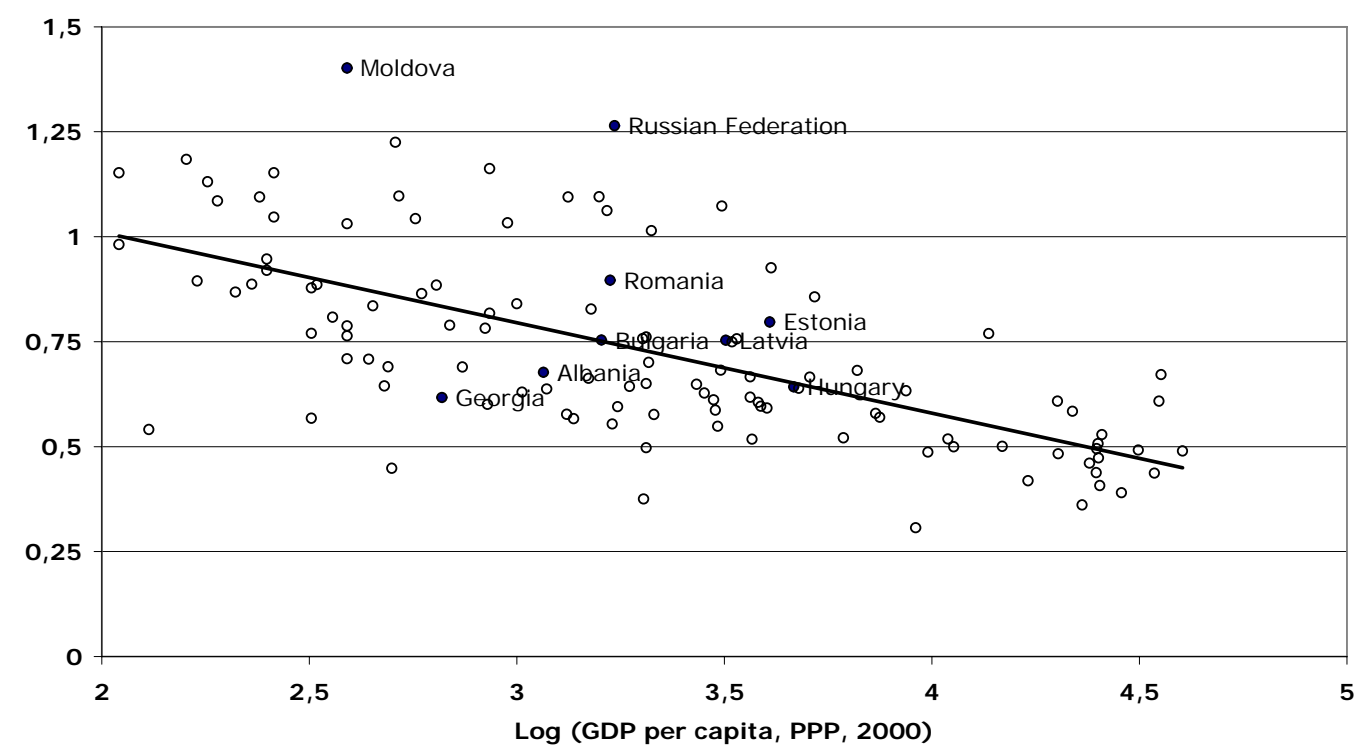

Note: The graph presents aggregate national wealth around the world and in transition countries in 2000. Source: World Bank (2005a).

Yet, this wealth is not equally distributed among the citizens of post-communist countries which has significant implications for economic growth and sustainability of reforms. Indeed, inequality, both income and wealth inequality, has an important and

1 Figure 1 presents national wealth including natural resources, production capital, infrastructure but excluding human capital. The graph for production capital/GDP looks similar. 
Table 1: Per capita wealth in transition countries, and selected OECD countries, USD

\begin{tabular}{|c|c|c|c|c|}
\hline Country & $\begin{array}{l}2000, \text { total } \\
\text { wealth }^{1}\end{array}$ & $\begin{array}{l}\text { 2005, financial } \\
\text { wealth }^{2}\end{array}$ & $\begin{array}{l}\text { 2000, produced } \\
\text { capital + urban land } \\
\text { only }^{3}\end{array}$ & $\begin{array}{l}2000, \text { total } \\
\text { wealth } \\
\text { excluding } \\
\text { human capital }^{3}\end{array}$ \\
\hline Albania & 17199 & & 1745 & 5637 \\
\hline Armenia & 15294 & & & \\
\hline Azerbaijan & 11447 & & & \\
\hline Belarus & 25447 & & & \\
\hline Bulgaria & 22866 & 1381 & 5303 & 8751 \\
\hline Croatia & 29437 & 6198 & & \\
\hline Czech Rep. & 25697 & 7564 & & \\
\hline Estonia & 31180 & & 18685 & 24967 \\
\hline Georgia & 21115 & & 595 & 2394 \\
\hline Hungary & 38411 & 6222 & 15480 & 20427 \\
\hline Kazakhstan & 23348 & & & \\
\hline Kyrgyzstan & 9745 & & & \\
\hline Latvia & 27468 & & 12979 & 18464 \\
\hline Lithuania & 29091 & & & \\
\hline Macedonia & 24144 & & & \\
\hline Moldova & 11577 & & 4338 & 7598 \\
\hline Poland & 35566 & 4493 & & \\
\hline Romania & 22127 & 818 & 8495 & 13003 \\
\hline Russia & 25755 & 1136 & 15593 & 32809 \\
\hline Slovak Rep. & 35786 & 4236 & & \\
\hline Slovenia & 46461 & & & \\
\hline Tajikistan & 5443 & & & \\
\hline Ukraine & 15141 & & & \\
\hline China & 11965 & & 2956 & 5179 \\
\hline France & 83016 & & 57814 & 64150 \\
\hline Germany & 89871 & & 68678 & 73124 \\
\hline Italy & 119704 & & 51943 & 56621 \\
\hline UK & 124861 & & 55239 & 62406 \\
\hline Euro zone & & 54300 & & \\
\hline Canada & 89252 & & 54226 & 88997 \\
\hline Japan & 115237 & & 150258 & 151771 \\
\hline US & 147665 & & 79851 & 94603 \\
\hline
\end{tabular}

Sources: ${ }^{1}$ Davis et al. (2006) (predicted or actual, PPP adjusted); ${ }^{2}$ Unicredit (2006), ${ }^{3}$ World Bank (2005a) (PPP adjusted). 
lasting effect on the institutional change (Glaeser et al. 2003; Sonin 2003). Moreover, as financial markets are imperfect, 2 wealth inequality is crucial for economic development, as wealth-constrained entrepreneurs cannot implement their business ideas. Banerjee and Newman (1993) show that in the absence of an effective court system and wellfunctioning financial markets wealth inequality breeds wealth inequality and may lock the economy in an underdevelopment trap.

The research on wealth inequality is plagued by an array of data problems (Davies and Shorrocks 2005). First, there are no consistent microeconomic data on personal wealth for transition countries. Whatever data are available are not comparable neither crosscountry nor over time. The wealth data for the pre-transition period are problematic for a number of reasons (see next section). Also, transition has been accompanied by a substantial growth of informal sector (Shleifer and Treisman 2005). What is more important, the growth of informal sector may have been very different in different countries (Alexeyev and Pyle 2003) and cannot be accurately measured (Hanousek and Palda 2005). Even given the imperfect data, there are a few strands of studies that promote our understanding of wealth inequality in transition.

First, as much of personal wealth distribution today is driven by the privatization process, the existing research on privatization provides important insights. Although the scholars of privatization also complain about the lack of data, substantial progress has been made (Megginson 2005; Guriev and Megginson 2006). In addition to privatization of industrial assets, the reforms have also transferred real estate to urban citizens and farm land to farmers. Prior to transition, socialist economies provided each citizen with a virtually free access to public housing. Transition has transformed these rights-to-use into private property rights essentially creating a market for real estate-consistent with the logic of De Soto (2002). In addition to registering the private property titles, transition has resulted in a significant increase of supply of housing in real terms. For example in Russia, a country traditionally plagued by the lack of housing, an average citizen has seen a 20 per cent increase in terms of per capita square meters during 19902004. The transfer of housing has contributed to an increase in wealth inequality as the value of housing in different locations varies greatly. 3

Second, there is substantial research on one of the most intriguing phenomena in transition: the emergence of a handful of super rich tycoons in Russia-so called 'oligarchs'. Out of 691 billionaires in the Forbes list of 2005, 27 are from Russia, by far

2 See Appendix on the degree of financial development in transition countries.

3 This is certainly a measurement issue - except for the De Soto's collateral argument, the rental service flow was the same before transition. Yet, as the differences in the value of the rental service flows were not properly measured, transition has resulted in an observed increase in inequality. See Yemtsov (2006) for a thorough empirical study of the effect of housing privatization on inequality in Poland, Serbia and Russia. Gustafsson and Li (2001) argue that in China much of the urban-rural inequality is due to the high value of the user rights for urban real estates that urban workers obtain at low rates. 
many more than from the other transition countries combined, including China (Figure 2). ${ }^{4}$ It is interesting to compare Russia's standing in the Forbes Billionaire List and in the World Wealth Report that cover the 'second-tier rich'-individuals with at least US\$1 million in financial assets. While Russia has 4 per cent of the world's billionaires both in terms of wealth and number of individuals, there are only 103,000 Russian millionaires (only 1.2 per cent of the world's total) who have about US\$670 billion wealth ( 2 per cent of the world's total). 5 The comparison of the Forbes List and the World Wealth Report suggests that there is a huge inequality at the very the top end of Russia's wealth distribution: 25 Russian oligarchs have about 12 per cent of the combined wealth of 103 thousand Russian millionaires. 6

How and why did these 'oligarchs' arise? Why did they emerge in Russia but not in other transition countries? What is the impact of their wealth on the economic development of Russia? We address these issues in detail below.

Figure 2: Russians in the Forbes' billionaires list

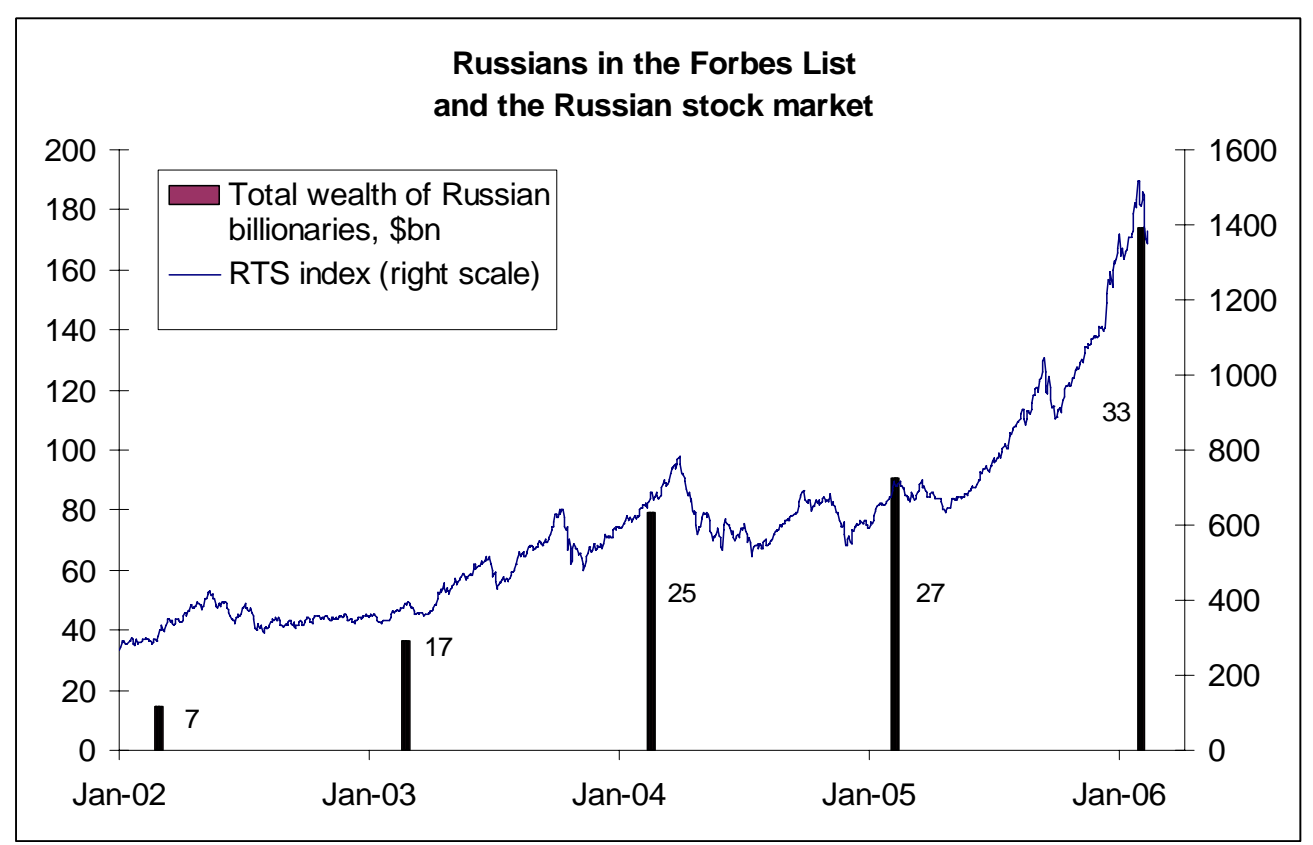

Note: Forbes estimates of the billionaires wealth are shown at the date of the publication of the list. The numbers next to bars indicate the number of Russian individuals in the Forbes list.

Source: Forbes (2002-2006), Russian Trading System website (www.rts.ru), and authors' calculations.

4 Actually, in the 2005 Forbes list, the total wealth of all non-Russian billionaires from transition countries (including China but excluding Hong Kong) was below the wealth of the single richest Russian. In 2004, the wealth of 26 Russian billionaires was about 19 per cent of Russian GDP; the total wealth of all 262 US billionaires was just 7 per cent USA GDP. The role of oligarchs increased even further in 2006 when their wealth doubled to US\$174 billion (23 per cent Russian GDP).

5 The 2005 World Wealth Report does not provide an estimate of the total wealth of Russian billionaires. We use the numbers of 544 and 573 billions for the 2002 and 2003 mentioned in the presentation of the 2004 World Wealth Report (Vedomosti 2004) and extrapolate them for the next year.

6 The World Wealth Report (2005) is based on 2004 data; hence it has to be compared to the Forbes List in 2004 when Russia had 25 billionaires jointly owning US\$80 billion. 
Third, the income inequality is studied and understood very well. Milanovic (1998) provides a comprehensive analysis of income inequality in transition based on the comparable data from household surveys in transition. Figure 3 illustrates the variety of transition experiences in terms of increases in income inequality. ${ }^{7}$

Figure 3: Income inequality Gini estimates are made in 1996-2002 period, for most countries in 2000-01

Gini

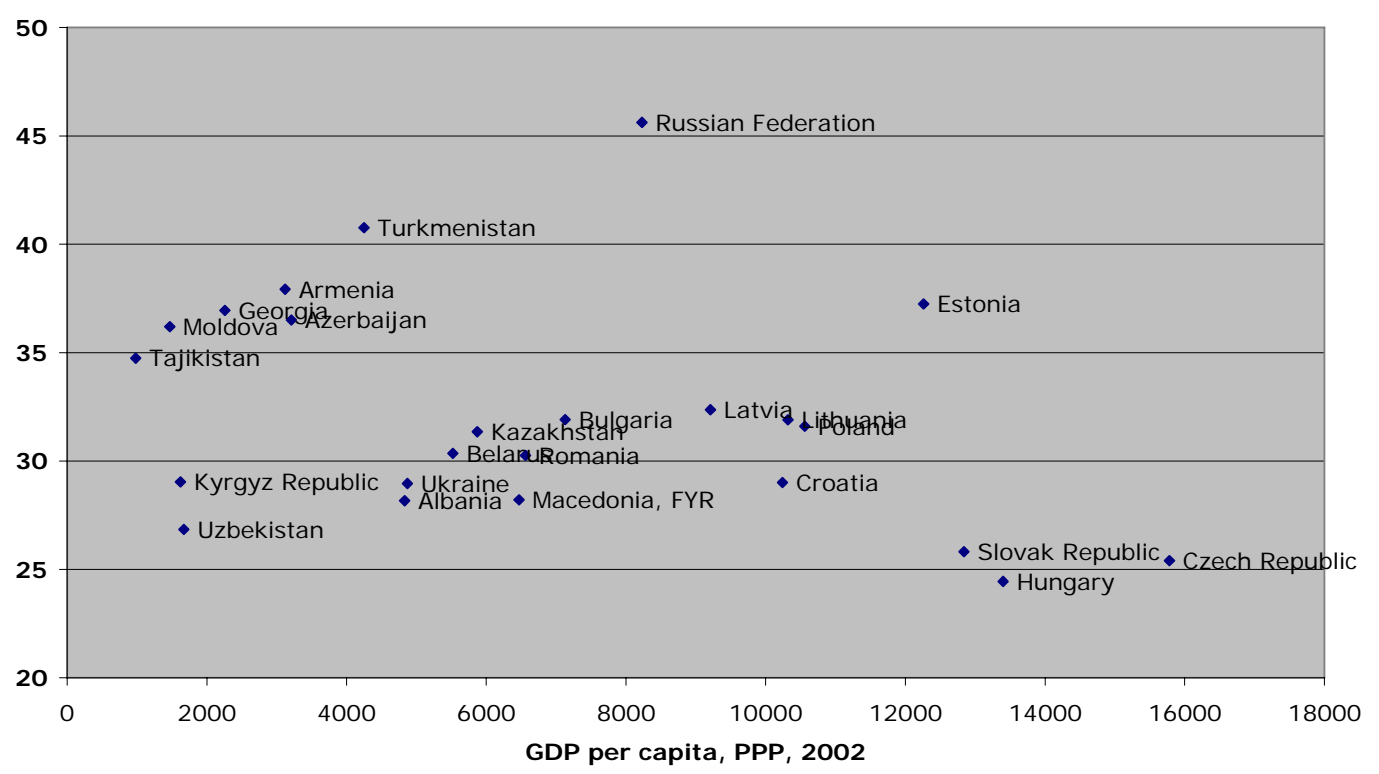

Source: World Development Indicators.

Given that prior to transition personal wealth inequality as well as personal wealth per se were quite low, the current wealth inequality is essentially a function of income inequality during the transition process. As transition countries are essentially middle income countries, the poor face a subsistence constraint, so that within each economy, the savings rates increase with income. Figure 4 shows that the lower half of Russian income distribution essentially saves nothing or even dissaves; the savings rates are substantial only in the top income quartile. The lower saving rates by the poor imply that the wealth inequality is much higher than income inequality.

This argument is incomplete without taking into account capital gains, in particular those on the public housing and productive assets transferred to private hands in the

7 This scatterplot is very intuitively divided into three clusters. Within each cluster there is a positive correlation between levels of income and inequality (interestingly, the relationship between changes in Gini and per capita is actually negative; Keane and Prasad 2002). One cluster is the advanced transition countries except Poland, the other one is the war-torn countries plus resource-rich Russia and Turkmenistan; other countries are in the third cluster. The fact that Poland is in the intermediate cluster may be explained by the high pre-transition inequality: actually the change in Poland's Gini was very small (Keane and Prasad 2002). 
course of transition. While there is no data for such an adjustment, it would probably further increase the estimated inequality. Indeed, the opportunities to earn higher income would be higher for individuals, regions, and sectors where such assets are more valuable and vice versa.

Figure 4: Majority of Russians saved very little or even dissaved during transition

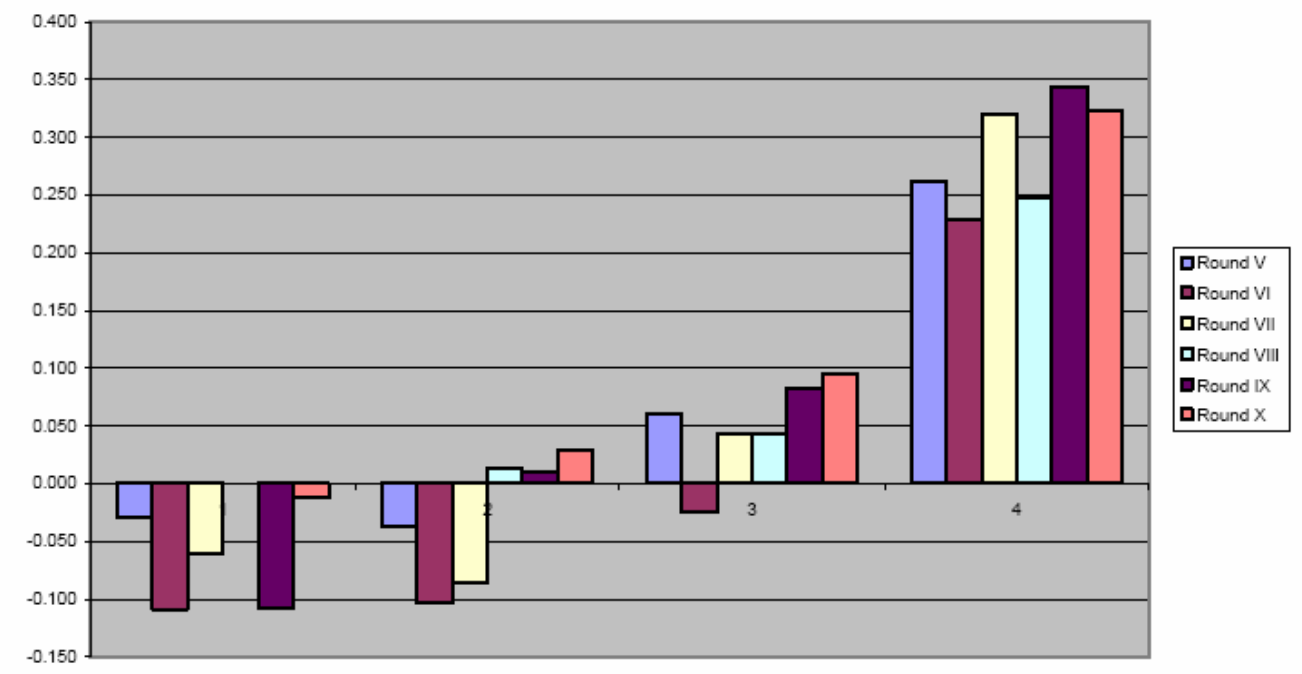

Note: The graph depicts savings rates (including durables) by income quartiles, based on Russian longitudinal monitoring survey (RLMS) survey, Rounds V-X (1994-2001).

Source: Foley and Pyle (2005).

\section{Initial conditions}

Our knowledge of inequality in the socialist economies is highly incomplete. The first problem is the lack of primary data. The official data have not been collected, so the most reliable information on inequality has come from the emigrant surveys. Ofer and Vinokur (1992) have surveyed 1,250 Soviet Jewish emigrants to Israel who provided information on their wealth prior to their decision to emigrate. These surveys suffer from two important methodological problems. The emigrants are certainly not a representative sample. Among other things, their decision to emigrate could be linked to their low wealth (it is therefore not surprising that 58 per cent of emigrants in the survey had no assets at all). Ofer and Vinokur recognize these problems and suggest that one should be very careful interpreting their wealth inequality estimates (indeed, the 0.7-0.8 Gini coefficient for the wealth distribution obtained by Ofer and Vinokur is strongly influenced by the large share of assetless migrants).

The other more important problem is that the pecuniary income/wealth inequality does not measure the true inequality of living standards in a command economy. First, there have been many missing markets (including real estate and financial markets). Second, the real inequality is not in having the wealth but in the ability to use this wealth to buy goods in shortage at state prices. These were driven by connections which in turn were a 
function of one's standing in the Soviet hierarchy. 8 The acuteness of shortage differed geographically. Those residing in larger cities would have access to much better provision of goods in stores. The mobility was constrained through the system of residence permits, so that relocation to a large city was a crucial non-monetary incentive. The factories also were happy to provide the skilled workers with fringe benefits such as good healthcare and housing - this legacy was still important during transition (Commander and Schankerman 1997; Friebel and Guriev 2005; Juurikkala and Lazareva 2004). Moreover, these problems differed across countries. While the share of public sector employment was very high everywhere, only in Yugoslavia and Poland public employment was below 90 per cent (Milanovic 1998), the share of private income varied from 5 to 25 per cent.

Table 2: The share of private income in socialist economies before transition (1988-89)

\begin{tabular}{lllllll}
\hline Income source & Czechoslovakia & USSR & Bulgaria & Hungary & Yugoslavia & Poland \\
\hline Primary income & 72.9 & 78.8 & 71.2 & 71.7 & 83.1 & 78.2 \\
Labour income & 69.5 & 72.0 & 56.5 & 55.0 & 62.2 & 53.0 \\
$\begin{array}{l}\text { Self-employment } \\
\text { income }\end{array}$ & 3.4 & 6.8 & 14.7 & 14.0 & 20.9 & 25.2 \\
Property income & n.a. & n.a. & n.a. & 2.7 & n.a. & n.a. \\
Social transfers & 25.4 & 13.6 & 21.2 & 22.4 & 13.3 & 20.7 \\
Pensions & 16.5 & 8.0 & 16.6 & 13.4 & 12.1 & 14.3 \\
Child benefits & 5.6 & 1.2 & 2.3 & 6.0 & 1.2 & 5.2 \\
Other cash transfers & 3.3 & 4.4 & 2.3 & 3.0 & 0.0 & 1.2 \\
Other income & 1.7 & 7.6 & 7.6 & 6.0 & 3.6 & 1.1 \\
Gross income & 100.0 & 100.0 & 100.0 & 100.0 & 100.0 & 100.0 \\
Personal taxes & 14.2 & n.a. & n.a. & 16.5 & 1.2 & 1.6 \\
Direct taxes & 0.0 & n.a. & n.a. & 10.7 & 1.2 & 1.6 \\
Payroll tax (employee) & 14.2 & 0.0 & 0.0 & 5.8 & 0.0 & 0.0 \\
Private income & 5.1 & 14.4 & 22.3 & 22.7 & 24.5 & 26.3 \\
\hline
\end{tabular}

Note: Private income is calculated as the self-employment income, property income and other income.

Source: Milanovic (1998).

\section{Reform strategies and inequality}

One of the most commonly held beliefs about transition is that the rise of inequality is due to the reform and to privatization in particular. This argument is especially popular among the scholars of Russian transition (Stiglitz 2003) and goes as follows: Russian reform has channeled state assets into the hand of a few, drastically reduced the government funding of public goods therefore leaving majority of citizens at or below the subsistence levels. The existing evidence suggests that the situation is more

8 See Shleifer and Vishny (1994) for this theory explaining why centrally planned economies needed shortages to provide incentives. 
involved. First, the income inequality has risen in all transition countries including China and Vietnam. Second, even in Russia the major increase in inequality occurred prior to privatization. Third, as shown by Milanovic (1999), most of the increase in income inequality in post-communist countries is due to wage decompression. 9 Yet, all of the above refers to income inequality. The dynamics of wealth inequality was also driven by the privatization process. Transition countries have chosen very different privatization strategies (Megginson 2005): some (most importantly, Russia and Czech Republic) opted for voucher-based mass privatization, others sold in open auctions allowing foreigners to bid, some sold to insiders, some did not privatize at all.

Figure 5: Change in Gini coefficient for transition countries and the contribution of wage decompression

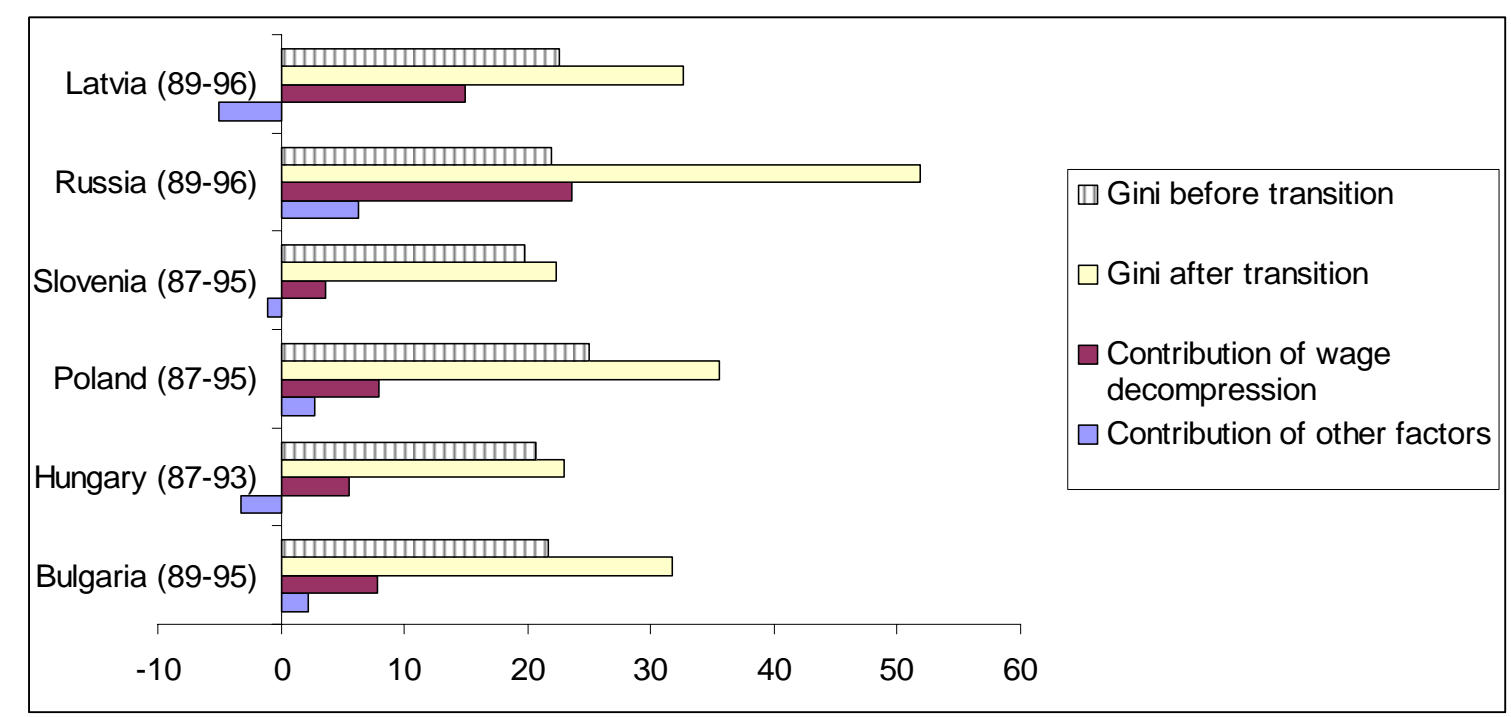

Source: Milanovic (1999).

The outcomes however do not depend very much on the privatization strategies. Rather, there is a clear distinction between Central and Eastern Europe (CEE) and former Soviet Union (FSU) transition experiences-Berglof and Bolton (2002) refer to this distinction as the Great Divide of transition. For example, with all the difference between Polish and Czech privatization strategies, the ownership structures in these countries are converging (Grosfeld and Hashi 2003; see also the Appendix). Even though the Czech Republic has had its share of corporate governance scandals (Johnson et al. 2000), in the end of the day the market institutions have emerged as the country joined the EU. Also, Russia has privatized extensively and is now renationalizing important sectors of the economy.

The simplest explanation of the Great Divide is the outside anchor of EU accession available to CEE countries. In these countries, the commitment to reforms was credible, while the FSU there has always been a fear of reversal and expropriation; the risk did

9 Milanovic's study ends in the 1990s but the levels of inequality in transition economies have remained roughly constant since then. 
materialize in Russia, Belarus, and some other countries. This has determined the choice of reform strategies. In order to provide demand for market institutions, reformers had to create a critical mass of private owners, and do that quickly. While the voucher privatization is suboptimal in terms of efficiency (Megginson 2005), it had to be implemented to make the reforms irreversible. 10 On the other hand, as reformers did realize already in the beginning of reforms and as the empirical research on privatization showed later (Guriev and Megginson 2006), privatization works better in the presence of complementary reforms of market and state institutions. Therefore the reformers faced a chicken-and-egg problem. In Russia, they chose to launch a rapid mass privatization to transfer tens of thousands of industrial enterprises to private hands (usually to incumbents) within the course of a couple of years. ${ }^{11}$ Initially, the assets were owned by tens of millions of Russians, but the ownership quickly consolidated. As the market institutions were underdeveloped, there were huge 'institutional economies of scale'-large owners have been able to influence the rules of the game through capturing regulators, courts and legislatures (Glaeser et al. 2003; Sonin 2003; Hellman et al. 2003; Slinko et al. 2005). Hence the shares changed hands from workers and retired workers to managers or outside majority owners. 12

The next wave of privatization was the so-called loans-for-shares programme. This programme was designed to overcome the parliament-imposed ban on privatization of mining industries. The government did not sell the assets; rather, government borrowed cash from private banks using the assets as collateral; as the government never intended to pay back, the assets were actually transferred to the bankers. As the auctions were run by the banks themselves, they were rigged and the assets were privatized at a small fraction of their market value (Freeland 2000). 13 Both loans-for-shares privatization and post-voucher-privatization consolidation of ownership resulted in an emergence of a few large business groups each owned by handful of entrepreneurs known as oligarchs.

\section{Oligarchs}

According to Plato, 'oligarchy' is a form of government by a small group; Plato distinguished oligarchs from nobles as the latter are few but rightful rulers while

10 The risk of policy reversal was the major factor for not adopting China's gradualist approach. The renationalization of a few key enterprises in 2004-05 implies that this risk was and still is very tangible. Unfortunately for the reformers, the rise in inequality due to hasty privatization has only strengthened public support for policy reversal.

11 Beck and Laeven (2006) show that the institutional challenges were especially important in transition countries with natural resources and with many years under communism. Russia has both.

12 One of the important factors in this process was the spread of wage arrears in Russia in the mid 1990s (Earle and Sabirianova 2002). As workers were not paid wages in time, they were desperate to get cash and sold their shares at very low prices.

13 The important factor was the 1996 presidential elections; loans-for-shares helped Yeltsin enlist support of the bankers (future oligarchs) as these assets would remain their property only in case of Yeltsin's victory. 
oligarchs come to power unlawfully. In its current meaning in Russia, the term 'oligarch' denotes a large businessman who controls sufficient resources to influence rules of the game-politics, regulation, and judiciary-to further their fortunes. As mentioned, transition has created oligarchs in Russia but not in other post-communist countries. Russia differs from other transition countries in several important respects. First, it holds vast natural resources which creates enormous potential for rent-seeking. Second, unlike the CEE countries, it has spent more time under communism; it was therefore more difficult to rebuild market institutions (no living Russian had memory of life in a capitalist economy). Besides, Russia did not have an outside anchor such as EU accession that has created commitment to building these institutions in the CEE. Third, Russia has undertaken a democratic and decentralized path of political reform which allowed for private agents to build their estates independent of the rulers. The latter factor is important for understanding the difference between Russia on one hand and authoritarian post-Soviet regimes, on the other. While the latter have successfully eliminated all private oligarchs, it is not clear how much wealth has been amassed by the rulers themselves. Due to the oppression of free press, such data are not available but even the sketchy evidence suggests that the post-Soviet authoritarian rulers are rich enough to be considered the 'ultimate oligarchs' within their own countries. 14

These distinguishing features of Russia's economy have predetermined the emergence of Russian oligarchs. While the conventional wisdom is that the Russian oligarchs were created by the loans-for-shares scheme discussed above, this is only a part of the picture. Indeed, among the 22 business groups listed in Table 3, only three (led by Potanin, Abramovitch and Khodorkovsky) owe their fortunes to this particular event as they have used the loans-for-shares auctions to acquire the crown jewels of the mining industry. Two more oligarchs - then industry incumbents Bogdanov and Alekperovhave used loans-for-shares to reinforce their control over their own enterprises. Others have risen through voucher privatization or through purchasing privatized firms from incumbents. 15 Moreover, the first list of omnipotent tycoons of Russia-the so-called 'Berezovsky's Group of Seven' - included four businessmen who actually lost all loansfor-shares tenders they took part in.

14 One of the most liberal of these rulers, Kazakh President Nursultan Nazarbayev has allegedly tunneled at least U $\$ 1$ billion of oil export revenues to one of his private accounts; his family controls many other key enterprises in the country (Kramner and Norris 2005; Hiatt 2005). Another common example is Ukraine where three groups (those of Taruta, Akhmetov and Pinchuk) have become the pillars of President Kuchma's regime (not surprisingly, Kuchma is Pinchuk's father-in-law) and did suffer a certain fallout after the Orange Revolution of 2004. Gorodnichenko and Grygorenko (2005) list 13 Ukrainian oligarchs (including Pinchuk, Ahmetov and Taruta) who jointly control about 40 per cent of the Ukrainian economy. Yet only three of them - the very same Pinchuk, Ahmetov and Taruta—showed up in the Forbes list.

15 Guriev et al. (2006) track all the private Russian owners in the World Bank's (2004) dataset and find that 42 per cent Russian firms were controlled in 2003 by owners who were industry insiders at the beginning of transition; 48 per cent of the firms are controlled by owners who have served in high government positions at some point in 1990s. The preliminary evidence in this paper suggests that while political connections help to get better assets, the politically-connected owners are less efficient owners in terms of productivity growth. 
Table 3 is borrowed from Guriev and Rachinsky (2005) who used a unique dataset on ownership of Russian industry in 2003 to classify the largest owners as oligarchs. In their sample covering about 75 per cent of Russian industry, the 22 oligarchs control about 40 per cent of sales and employment. It is therefore not surprising to see astonishing estimates of their personal wealth in the Forbes list. What do we know about Russian oligarchs? First, they do control enterprises in natural resource industries and in protected industries such as automotive (Guriev and Rachinsky 2005). Their market shares in the industries that they control are very large. Yet, it should not be a concern for the antitrust policy as almost all of these industries produce globally tradable goods. What is more important is the 'political antitrust' (Rajan and Zingales 2003) policies restricting the state capture by the large influential business groups. Even though the oligarchs are small in the global economy, they have a huge weight within Russia.

Table 3: Russian oligarchs as of mid 2003

\begin{tabular}{|c|c|c|c|c|}
\hline Senior partner(s) & $\begin{array}{l}\text { Holding company/firm, } \\
\text { major sector(s) }\end{array}$ & $\begin{array}{l}\text { Employment, in } \\
\text { thousands (\% of } \\
\text { sample) }\end{array}$ & $\begin{array}{l}\text { Sales, in billions } \\
\text { of rubles (\% of } \\
\text { sample) }\end{array}$ & $\begin{array}{l}\text { Wealth, in } \\
\text { US\$ billions }\end{array}$ \\
\hline Oleg Deripaska & $\begin{array}{l}\text { Base Element/RusAl, } \\
\text { aluminum, auto }\end{array}$ & 169 (3.9) & $65(1.3)$ & 4.5 \\
\hline Roman Abramovich & $\begin{array}{l}\text { Millhouse/Sibneft, } \\
\text { oil }\end{array}$ & 169 (3.9) & 203 (3.9) & 12.5 \\
\hline Vladimir Kadannikov & $\begin{array}{l}\text { AutoVAZ, } \\
\text { automotive }\end{array}$ & $167(3.9)$ & $112(2.2)$ & 0.8 \\
\hline $\begin{array}{l}\text { Sergei Popov, } \\
\text { Andrei Melnichenko, } \\
\text { Dmitry Pumpiansky }\end{array}$ & $\begin{array}{l}\text { MDM, } \\
\text { coal, pipes, chemical }\end{array}$ & $143(3.3)$ & $70(1.4)$ & 2.9 \\
\hline Vagit Alekperov & $\begin{array}{l}\text { Lukoil, } \\
\text { oil }\end{array}$ & $137(3.2)$ & $475(9.2)$ & 5.6 \\
\hline Alexei Mordashov & $\begin{array}{l}\text { Severstal, } \\
\text { steel, auto }\end{array}$ & $122(2.8)$ & $78(1.5)$ & 4.5 \\
\hline $\begin{array}{l}\text { Vladimir Potanin, } \\
\text { Mikhail Prokhorov }\end{array}$ & $\begin{array}{l}\text { Interros/Norilsk Nickel, } \\
\text { non-ferrous metals }\end{array}$ & $112(2.6)$ & $137(2.6)$ & 10.8 \\
\hline Alexandr Abramov & $\begin{array}{l}\text { Evrazholding, } \\
\text { steel }\end{array}$ & $101(2.3)$ & $52(1.0)$ & 2.4 \\
\hline $\begin{array}{l}\text { Len Blavatnik, } \\
\text { Victor Vekselberg }\end{array}$ & $\begin{array}{l}\text { Access-Renova/TNK-BP, } \\
\text { oil, aluminum }\end{array}$ & $94(2.2)$ & $121(2.3)$ & 9.4 \\
\hline Mikhail Khodorkovsky & $\begin{array}{l}\text { Menatep/Yukos, } \\
\text { oil }\end{array}$ & $93(2.2)$ & 149 (2.9) & 24.4 \\
\hline Iskander Makhmudov & $\begin{array}{l}\text { UGMK, } \\
\text { non-ferrous metals }\end{array}$ & $75(1.7)$ & $33(0.6)$ & 2.1 \\
\hline Vladimir Bogdanov & $\begin{array}{l}\text { Surgutneftegaz, } \\
\text { oil }\end{array}$ & $65(1.5)$ & $163(3.1)$ & 2.2 \\
\hline Victor Rashnikov & $\begin{array}{l}\text { Magnitogorsk Steel, } \\
\text { steel }\end{array}$ & $57(1.3)$ & $57(1.1)$ & 1.3 \\
\hline Igor Zyuzin & $\begin{array}{l}\text { Mechel, } \\
\text { steel, coal }\end{array}$ & $54(1.3)$ & $31(0.6)$ & 1.1 \\
\hline
\end{tabular}




\begin{tabular}{|c|c|c|c|c|}
\hline Vladimir Lisin & $\begin{array}{l}\text { Novolipetsk Steel, } \\
\text { steel }\end{array}$ & $47(1.1)$ & $39(0.8)$ & 4.8 \\
\hline $\begin{array}{l}\text { Zakhar Smushkin, } \\
\text { Boris Zingarevich, } \\
\text { Mikhail Zingarevich }\end{array}$ & $\begin{array}{l}\text { IlimPulpEnterprises, } \\
\text { pulp }\end{array}$ & $42(1.0)$ & $20(0.4)$ & 1 \\
\hline Shafagat Tahaudinov & $\begin{array}{l}\text { Tatneft, } \\
\text { oil }\end{array}$ & $41(1.0)$ & $41(0.8)$ & 2.9 \\
\hline Mikhail Fridman & $\begin{array}{l}\text { Alfa/TNK-BP, } \\
\text { oil }\end{array}$ & $38(0.9)$ & $107(2.1)$ & 5.2 \\
\hline Boris Ivanishvili & $\begin{array}{l}\text { Metalloinvest, } \\
\text { ore }\end{array}$ & $36(0.8)$ & $15(0.3)$ & 8.8 \\
\hline Kakha Bendukidze & $\begin{array}{l}\text { United Machinery, } \\
\text { engineering }\end{array}$ & $35(0.8)$ & $10(0.2)$ & 0.3 \\
\hline $\begin{array}{l}\text { Vladimir } \\
\text { Yevtushenkov }\end{array}$ & $\begin{array}{l}\text { Sistema/MTS, } \\
\text { telecoms }\end{array}$ & $20(0.5)$ & $27(0.5)$ & 2.1 \\
\hline $\begin{array}{l}\text { David Yakobashvili, } \\
\text { Mikhail Dubinin, } \\
\text { Sergei Plastinin }\end{array}$ & $\begin{array}{l}\text { WimmBillDann, } \\
\text { dairy/juice }\end{array}$ & $13(0.3)$ & $20(0.4)$ & 0.2 \\
\hline Total & & $1,831(42.4)$ & $2,026(39.1)$ & \\
\hline
\end{tabular}

Note and source: Employment and sales are from World Bank (2004) and Guriev and Rachinsky (2005). The percentages in parentheses is the share of employment/sales of the World Banks sample, that in turn covers a substantial share of the economy as discussed below. Wealth is the market value of the oligarchs' stakes in spring 2004 calculated by authors using Forbes 2004 and stock market data. Wealth includes stakes of all the partners identified by the survey (in most cases, there is just one major owner, but in some cases there are 2-3 or even 7). Each entry lists the leading shareholder(s) in a respective business group, the name of the holding company or the flagship asset, and one or two major sectors. We report several individuals per group only when there is equal or near equal partnership. Ranking is based on employment in the sample and may therefore be different from actual, as the sample disproportionally covers assets of different oligarchs. Employment and sales are based on official firm-level data for 2001. The exchange rate was US $\$ 1=29$ rubles.

Most of the oligarchs in Table 3 are relatively young. The average/median Russian billionaire is about 45 years old, 20 years younger than an average/median billionaire in the USA. Most of them control majority or supermajority stakes in their companies which they are still actively managing. The absence of separation of ownership and control and resulting agency problems has provided the oligarchs with strong incentives to restructure their firms. Boone and Rodionov (2002) argue that since the oligarchs established - often through expropriation and dilution of other shareholders including the state - the control over their assets, they have been running them very well. This claim is consistent with preliminary evidence in Shleifer and Treisman (2005) and Guriev and Rachinsky (2005) who show that oligarchs seem to outperform other Russian owners and almost catch up with foreign owners.

Moreover, consistently with reformer's expectations, oligarchs began to lobby for certain further pro-market reforms (Guriev and Rachinsky 2005). This process however took more time than the reformers expected and was also less comprehensive. First (as suggested by Glaeser et al. 2003; Sonin 2003), oligarchs originally benefited from continued rent-seeking. Second, unlike robber barons in the USA, Russian oligarchs are a part of a globalized economy (a few oligarchs from Table 2 live in London, most 
prominently Roman Abramovic), hence their commitment to building long-term security of property rights in Russia is rather limited.

The oligarchs' incentives are also weakened by the insecurity of their property rights. A median Russian voter deems oligarchs' property rights illegitimate and supports their expropriation (see a discussion of poll data in Guriev and Rachinsky 2005; and Vedomosti 2003b). This is well understood by all Russian politicians who use the threat of expropriation to obtain political or pecuniary contributions from the oligarchs. In particular, President Putin has used the anti-oligarch sentiment in his campaign in 2000; once he came to power, he offered the oligarchs the following pact. As long as the oligarchs paid taxes and did not use their political power (at least not against Putin), Putin would respect their property rights and refrain from revisiting privatization. This pact defined the ground rules of oligarchs' interaction with central and regional government for Putin's first term (2000-04). Although the pact could have never been written down, even general public was well aware of its existence. A poll by FOM (an independent non-profit Russian polling organization) a week after the meeting of Putin and the oligarchs showed that 57 per cent Russians knew about it.

Putin proved the credibility of the expropriation threat in 2003, when the prominent oligarch Mikhail Khodorkovsky, the majority owner of the Yukos oil company, deviated from the pact by openly criticizing corruption in Putin's administration 16 and supporting opposition parties and independent media (Vedomosti, 2003a). He and his partners were soon arrested or forced into exile, and their stakes in Yukos expropriated. Khodorkovsky was sentenced to eight years in prison, and his personal estate is now estimated to be only 2 billion dollars (down from 15 billion dollars).

The Yukos affair has clarified the rules of the game between oligarchs and the Kremlin. Oligarchs have learned the risks related to violating the pact, and so in the future, they will be less likely to interfere in national politics. Ironically, by crushing Russia's most transparent company, Putin has pursued the 'political antitrust' policy that was crucial in building US democracy and economy in the beginning of twentieth century (Rajan and Zingales 2003). Even though oligarchs remain economically powerful, they have no longer any role in politics. This in turn removed any counterweights to bureaucracy which then followed a steady course for renationalization. The nationalization occurs through buyout of oligarch firms by state-owned companies. In some cases, the oligarchs receive a large share of their assets' market value, in others just a fraction. 17 Therefore any wealth estimate based on the assets' market value (as those provided by

16 The Moscow Times, 'Tycoons Talk Corruption in Kremlin', 20 February 2003: 5.

17 As the threatpoint is the full expropriation, one should expect that even if assets are acquired by the state at the market value, the seller is asked to make substantial side payments. A prominent Russian journalist Yulia Latynina suggests that this was the case in the purchase of Sibneft from Abramovich (Echo Moskvy, 11 March 2006, www.echo.msk.ru/programmes/code/42280). 
Forbes) may substantially overestimate the true wealth of the oligarchs; the wealth depends both on the value of the assets and on the relationship with the government.

In the next year or two the nationalization of the key oligarch-controlled assets will continue. At the time of writing the paper, 4 out of 22 groups in the Table 3 are nationalized (Abramovich's Sibneft, the main division of Khodorkovsky's Yukos, Kadannikov's Avtovaz, Bendukidze's UMZ) and 2-3 more nationalizations are being discussed. Given the notorious inefficiency and corruption of Russian bureaucracy, these companies will eventually have to be reprivatized. If they are privatized in an open and competitive fashion, the public will respect the new owners' property rights which will in turn result in efficient incentives to invest. Yet another option is to reprivatize these companies to dispersed owners. This will provide Russian middle class with a stake in the financial development and economic growth and even increase their personal wealth. As shown in Megginson (2005), privatization IPOs are usually underpriced by about 30 per cent. Yet, if government fails to enforce post-IPO corporate governance, the dispersed owners may fail to reap the value of their investment.

Whether a direct sale to a strategic investor or share issue privatization (SIP) is selected or the two approaches are combined is yet to be seen. In principle, these companies are sufficiently large so that SIPs may be more efficient (Megginson 2005). The management of state-owned companies is biased towards SIP; indeed, if they have stakes in their companies, they would rather benefit from a liquid market where they can cash in. They will also be better-off under dispersed ownership as there will be less shareholder monitoring so they will preserve the private benefits of control.

However, the most important choice is not the one of the method of privatization but about the government's commitment to transparent rules of reprivatization. 18 If the privatization auctions/IPOs are rigged again, the new buyers will benefit in the short term, but the vicious circle of illegitimate property rights will result in another expropriation. This may create a stable equilibrium like in Acemoglu and Robinson (2001) - high wealth inequality breeds support for expropriation, but as political institutions are underdeveloped, the redistribution benefits the bureaucrats (who become the new rich) rather than the poor; therefore high inequality may persist for quite a while.

\footnotetext{
18 A reprivatization of Krivoryzhstal in Ukraine provide an important illustration of the argument (Kramer and Timmons 2005). In 2004, this crown jewel of Ukrainian steel industry was privatized to two out of three most influential Ukrainian oligarchs at US\$0.85 billion. The public outrage over the rigged auction was one of the important drivers of the Ukrainian Orange Revolution. The new government cancelled the privatization of the plant and resold it in an open tender for US\$4.8 billion to a leading global player. The high price and the transparency of the auction have secured public support for the property rights.
} 


\subsection{Measuring inequality in the presence of super-rich individuals: evidence from Moscow income tax data}

Given the presence of a score of billionaires and another 0.2 per cent households of millionaires in Russia, one has to question the reliability of the Gini indices that are obtained through household surveys. Indeed, all the estimates of Gini for Russia are based on surveys of households that probably include none of the millionaires. As these super-rich own a substantial share of the national wealth, including them should change the Gini estimates significantly. 19

In order to check the potential bias in Gini data, we looked at data that describes income (albeit not wealth) of all Moscow residents including most of the Russian billionaires in Table 3 and probably many of the 88,000 millionaires (the number of millionaires in Russia in 2004 according to World Wealth Report 2005). This is the database of 2004 income tax paid by and/or withheld on behalf of all Moscow residents built by Moscow tax inspections and leaked to the public domain. 20

The database contains more than 9 million entries; there can be several entries per person when a person receives income from multiple sources. We have concentrated on labour income as the other income categories are negligible; 21 in any case, including them would further increase our Gini estimate. Russia's tax code provides incentives to distribute profits as wage payments to owners (the corporate profit tax is 24 per cent, while the personal income tax is 13 per cent and the social payments by employers are regressive reaching 2 per cent marginal rates for wages above $\$ 20,000$ a year). After adding all labour income entries for each individual and cleaning obvious typos, we ended up with 6.1 million taxpayers. These included the very rich Russians although their incomes were far below the increase in their wealth as estimated by Forbes. The top income is only $\$ 15$ million; a median billionaire has only earned $\$ 1.5$ million in 2004. Figure 6 presents the distribution.

Even with these modest estimates of the incomes of Russian billionaires, our estimates for inequality are striking. The top 10 per cent of individuals earn 50 per cent of the total income. The Gini coefficient is 0.625 ! The official data for Gini in Russia in 2004 are 0.407. The independent representative (but a much smaller) RLMS household survey provides a Gini of 0.345 for the total income and 0.461 for the labour income (Table 4).

\footnotetext{
19 World Bank (2006) estimates that if the rich were included into household surveys in Azerbajan, Gini would go up from 0.20 to $0.45-0.55$.

20 Vedomosti (2005) discusses the authenticity of the database.

21 The only exception is the 'income from selling securities' category. These however turned out to be a proxy for financial intermediation - the highest incomes in this category included only brokerage house owners and employees.
} 
Figure 6: The distribution of annual income in Moscow based on income tax data

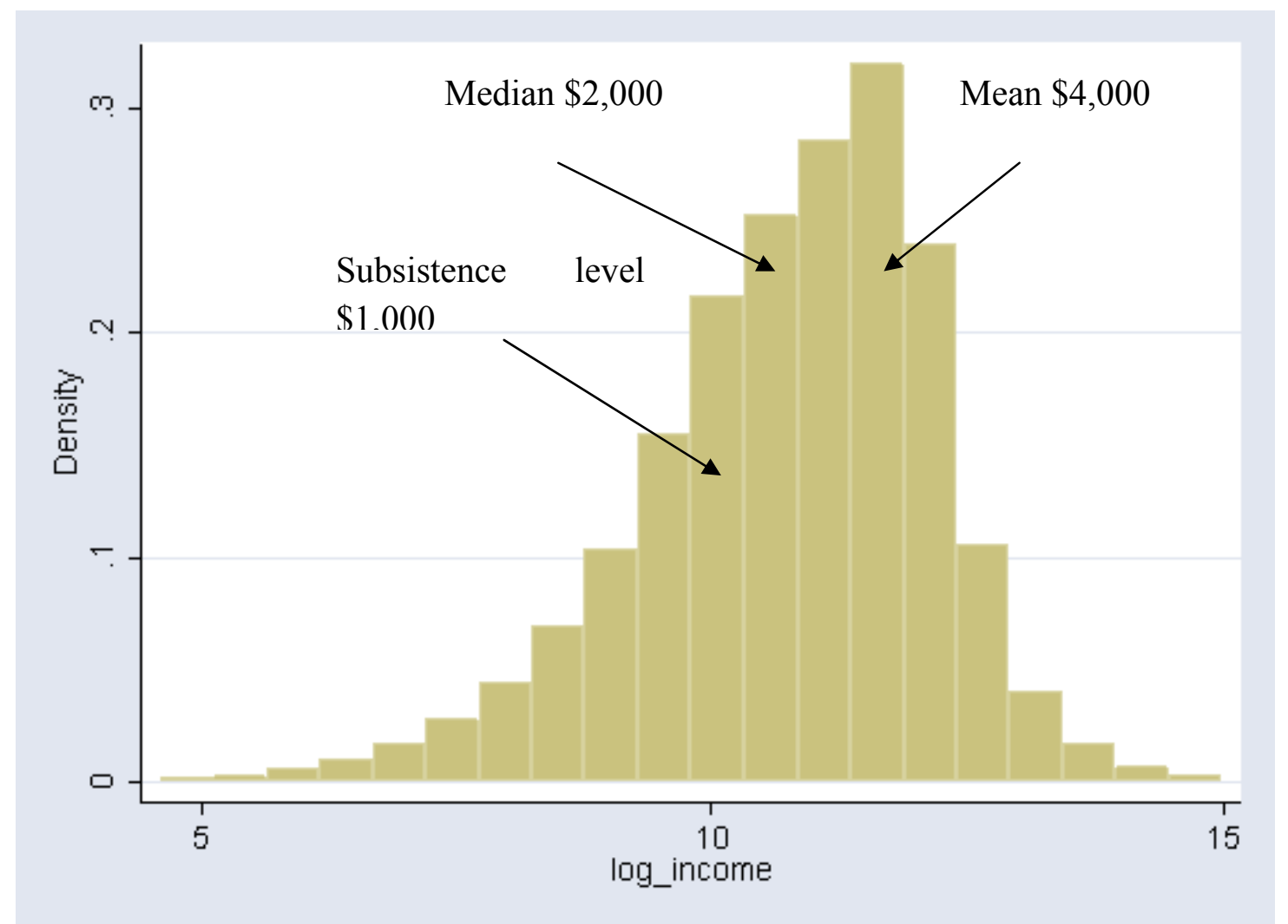

Note: The horizontal axis: In(income) where income is in rubles; the exchange rate was US\$1=29 rubles.

How do the inequality estimates for Moscow compare to that for Russia? There are no official regional estimates of inequality in Russia, and RLMS is not regionally representative. 22 We have used the National survey of household budgets and access to social services (NOBUS). NOBUS was conducted in 2003 and covered about 117 thousand individuals in 79 regions. NOBUS is both nationally and regionally representative. In Moscow NOBUS includes 2,100 respondents out of which 1,139 provided information on their labour income. As expected this survey does not cover the top income quantiles of Muscovites. The median income in NOBUS is about the same as in the tax data, but the mean is substantially lower. The top NOBUS income would be in the richest 2 per cent in the tax data, however, already the second richest NOBUS respondent is only at the top 10 per cent of the tax data. Therefore it is not surprising that NOBUS estimate for Gini is only 0.279.

22 Russian Statistics Agency (Rosstat, formerly Goskomstat) publishes regional Gini coefficients but the methodology is at best problematic. Goskomstat assumes that the true distribution is lognormal, and calculate the distribution's parameters using median and mean from regional household surveys. The median and mean are also adjusted to account for the gap between survey-based and macroeconomic accounts-based aggregate incomes. Interestingly, this methodology does result in a very high Gini for Moscow close to ours. But Moscow is even more problematic as it stands out in Goskomstat methodology as the only region for which Goskomstat adjusts the distribution manually by assigning weights that are somewhat arbitrary. We are grateful to Goskomstat and to Ruslan Yemtsov for describing this methodology to us. 
Table 4: Gini estimates in Russia in 2004, according to various sources

\begin{tabular}{ll}
\hline Source & Gini coefficient \\
\hline Household Budget Survey, Goskomstat, Russia & 0.407 \\
Russian longitudinal monitoring Survey (RLMS), labour income & 0.345 \\
Russian longitudinal monitoring Survey (RLMS), total income & 0.461 \\
National survey of household budgets and access to social & 0.279 \\
services (NOBUS), labour income, Moscow, 2003 & \\
Tax income data, labour income, Moscow & 0.625 \\
\hline
\end{tabular}

One of the potential problems with the tax data is that there may be a much higher degree of income underreporting at the lower end of the distribution rather at the top end. In order to provide a very conservative lower bound for our estimate, we replaced all income below the minimum living standard (about \$2.7 a day) with the minimum living standard. Even in this case (which assumes away any poverty in Moscow) we obtain a Gini coefficient of 0.563 .

These results should be taken with a grain of salt, as there are numerous caveats. Yet, this simple exercise suggests that in the presence of very rich individuals, the regular household surveys that exclude such individuals substantially underestimate inequality - by as much as 10-15 Gini percentage points. In particular, income inequality in Russia may be much higher than we believe; it can be at the level of Brazil, rather than at the level of the US. The data issues are therefore even more important than they seem to be at the first glance.

\section{$5 \quad$ Policy issues}

Is there a simple solution for the wealth inequality problem? Given high corruption (often driven by the very same inequality), redistribution does not necessarily benefit the poor. And unless the corruption is reined in, the expropriation of oligarchs will only create new oligarchs. It is therefore crucial to remove the fundamental cause of growth in wealth inequality, the 'institutional economies of scale'. As the market and government institutions are underdeveloped, the rich have an advantage in furthering their riches while the poor are denied opportunity. The transition countries should therefore focus on providing equal access to education and healthcare, 23 to the judiciary system and to financial markets.

The institutional reforms of the kind require government's commitment. Unfortunately, commitment to reform is in turn harder to assure in unequal societies; high wealth inequality reduces stability of economic policy in both democratic and authoritarian

23 In this respect, the transition countries, especially the CIS, are yet to make the turnaround (World Bank $2005 \mathrm{~b}$ ). The access to public goods, to quality education and healthcare is still not improving after a decline in the beginning of transition, and the situation is especially dire for the poor. 
regimes (in the latter, the stability of the regime itself is undermined). In the CEE countries, such commitment is provided by the outside anchor of the EU accession and most of the preconditions for reducing the inequality are already in place.

Commonwealth of Independent States (CIS) countries have mostly lagged behind the accession countries in terms of building market institutions, albeit to a varying extent. The list of institutions to be introduced is long. First, households need to have access to savings, investment, credit and insurance. For this, the government should support competition in the financial markets, but also introduce prudential regulation, regulation of stock market, credit history bureaus, deposit insurance system. Second, property rights for real estate should be established and the real estate market should be efficient. This is a major innovation for post-communist countries and it requires an overhaul of legislation and creation of a land registry. Third, the government should protect the property rights of entrepreneurs, both from racketeering and from predation from its own corrupt bureaucrats.

Every CIS country has taken some of the steps above and none has completed all of them. It is probably going to take more time than the reformers envisioned in the beginning of transition. While these institutions benefit the median voter, the problem is that in some of these countries the democratic transition is stifled or even reversed. Hence the policy choices may be biased in favour of the ruling elite which is happy to continue redistribution from the middle class. Moreover, reducing the wealth inequality may empower the middle class and therefore endanger the power of the entrenched elites. Thus it remains to be seen whether and how CIS countries manage to break out from the high inequality trap.

\section{Conclusions}

Given the lack of reliable data on personal wealth, it is hard to speculate on the evolution of personal wealth and of wealth inequality in transition countries. Yet, the indirect evidence points to a stark increase both in average personal wealth and in wealth inequality, especially in the former Soviet Union. While much of the income inequality is explained by the wage decompression, the wealth inequality was in many cases driven by privatization and subsequent consolidation of ownership. In particular, in Russia, the transition resulted in an emergence of a new class of rich individuals. While these oligarchs have restructured their companies and lobbied for further promarket reforms, the median voter's perception of their illegitimacy has undermined the government's incentive to continue reforms. It is therefore not surprising that in Russia, as well as in the other CIS countries, inequality has remained high and reforms, that could eventually bring it down, have been abandoned or even reversed. On the other hand, in the CEE countries, the outside anchor of EU accession has provided the governments with a commitment device to introduce institutions for greater equality of opportunity. 
Like many other papers on wealth inequality, ours concludes by restating the obvious need for more data. To illustrate the sheer extent of potential mismeasurement, we have estimated Gini index for income using the only database that includes Russia's superrich individuals; we found that the official data may underestimate Gini by about 25 percentage points. The wealth inequality data are probable even more distorted. An informed policy debate can only be based on reliable and comparable data on personal wealth coming from representative household surveys which would indeed include some very rich individuals. Unfortunately, such data are still non-existent.

\section{References}

Alexeyev, M., and W. Pyle (2003). 'A Note on Measuring the Unofficial Economy in the Former Soviet Republicsю', Economics of Transition 11(1): 153-75.

Banerjee, A., and A. Newman (1993). 'Occupational Choice and the Process of Development', Journal of Political Economy 101: 274-98.

Beck, T., and L. Laeven (2006). 'Institution Building and Growth in Transition Economies', CEPR Discussion Paper 5718, Centre for Economic Policy Research: London.

Berglof, E., and P. Bolton (2002). 'The Great Divide and Beyond: Financial Architecture in Transition', The Journal of Economic Perspectives 16(1): 77-100.

Boone, P., and D. Rodionov (2002). 'Rent seeking in Russia and the CIS', Brunswick UBS Warburg: Moscow.

Commander, S., and M. Schankerman (1997). 'Enterprise Restructuring and Social Benefits', Economics of Transition 5(1): 1-24.

Davies, J., and A. Shorrocks (2005). 'Wealth Holdings in Developing and Transition Countries', paper for the Luxembourg Wealth Study conference on Construction and Usage of Comparable Microdata on Wealth, 27-29 January, Perugia.

De Soto, H. (2000). The Mystery of Capital: Why Capitalism Triumphs in the West and Fails Everywhere Else, Basic Books: New York.

Earle, J., and K. Sabirianova (2002). 'How Late to Pay? Understanding Wage Arrears in Russia', Journal of Labour Economics 20(3): 661-707.

Freeland, C. (2000). Sale of the Century: Russia's Wild Ride from Communism to Capitalism, Crown Business: New York.

Foley, M., and W. Pyle (2005). 'Household Savings in Russia During the Transition', mimeo, Middlebury College: Middlebury VT.

Friebel, G., and S. Guriev (2005). 'Attaching Workers Through In-kind Payments: Theory and Evidence from Russia', World Bank Economic Review September. 
Glaeser, E., J. Scheinkman, and A. Shleifer (2003). 'The Injustice of Inequality', Journal of Monetary Economics Carnegie-Rochester Series on Public Policy 50(1): 199-222.

Gorodnichenko, Y., and Y. Grygorenko (2005). 'Are Oligarchs Productive? Theory and Evidence', mimeo, University of Michigan.

Grosfeld, I., and I. Hashi (2003). 'Mass privatisation, corporate governance and endogenous ownership structure', William Davidson Institute Working Paper 596.

Guriev, S., and W. Megginson (2006) 'Privatization: What Have We Learned?', forthcoming in F. Bourgoinon and B. Pleskovic (ed.) Beyond Transition: Proceedings of the Annual Bank Conference on Development Economics, World Bank: Washington DC.

Guriev, S., and A. Rachinsky (2005). 'The Role of Oligarchs in Russian Capitalism', Journal of Economic Perspectives 19(1): 131-50.

Guriev, S., A. Rachinsky, and E. Zhuravskaya (2006). 'The Genesis of Oligarchs', mimeo, CEFIR: Moscow.

Gustafsson, B., and S. Li (2001). 'Effects of the Transition on the Distribution of Income in China: A Study Decomposing the Gini Coefficient for 1988 and 1995', Economics of Transition 9(3): 593-618.

Hanousek, J., and F. Palda (2005). 'Mission Implausible III: Measuring the Informal Sector in a Transition Economy using Macro Methods', mimeo, CERGE-EI: Prague.

Hellman, J., G. Jones, and D. Kaufman (2003). 'Seize the State, Seize the Day: State Capture, Corruption, and Influence in Transition', Journal of Comparative Economics 31(4): 751-73.

Hiatt, F. (2005). 'Truth-Tellers in a Time of Terror', The Washington Post, 25 November.

Johnson, S., R. La Porta, F. Lopez-de-Silanes, and A. Shleifer (2000). 'Tunneling', American Economic Review Papers and Proceedings May.

Juurikkala, T., and O. Lazareva (2004). 'The Role of Social Benefits in the Employment Strategies of Russian Firms', mimeo, Helsinki School of Economics: Helsinki.

Keane, M., and E. Prasad (2002). 'Inequality, Transfers and Growth: New Evidence from the Economic Transition in Poland', Review of Economics and Statistics 84(2): $324-41$.

Kramer, A., and H. Timmons (2005). 'World's Biggest Steel Maker Is Acquiring Ukrainian Mill', The New York Times, 25 October.

Kramer, A., and F. Norris (2005). 'Amid Growing Wealth, Nepotism and Nationalism in Kazakhstan', The New York Times, 23 December. 
Megginson, W.L. (2005). The Financial Economics of Privatization (first edition), Oxford University Press: New York.

Milanovic, B. (1998). Inequality and Poverty During the Transition From Market Economy, World Bank: Washington DC.

Milanovic, B. (1999). 'Explaining the increase in Inequality During Transition', Economics of Transition 7(2): 299-341.

Ofer, G., and A. Vinokur (1992). The Soviet Household Under the Old Regime: Economic Conditions and Behavior in the 1970s, Cambridge University Press: Cambridge.

Rajan, R., and L. Zingales (2003). Saving Capitalism from the Capitalists: Unleashing the Power of Financial Markets to Create Wealth and Spread Opportunity, Crown Business: New York.

Shleifer, A., and D. Treisman (2005). 'Normal Country: Russia after Communism', Journal of Economic Perspectives 19(1): 151-74.

Shleifer, A., and R. Vishny (1994). 'The Politics of Market Socialism', Journal of Economic Perspectives 8(2): 165-76.

Slinko, I., E. Yakovlev, and E. Zhuravskaya (2005). 'Laws for Sale: Evidence from Russia', American Law and Economics Review 7(1): 284-318.

Sonin, K. (2003). 'Why the Rich May Favour Protection of Property Rights', Journal of Comparative Economics 31(4): 715-31.

Stiglitz, J. (2003). Globalization and its Discontents, W.W. Norton: New York.

Unicredit (2006). New Europe Households' Wealth and Debt Monitor.

Vedomosti (2003a). 'Khodorkovsky Confessed: Yukos Shareholders Will Support Union of Right Wing Forces, Yabloko, and the Communist Party', 8 April (in Russian).

Vedomosti (2003b). 'Take Away and Divide: People's Aspirations Have Not Changed in 86 years', 18 July (in Russian).

Vedomosti (2004). 'Money Breeds Money’, 16 June (in Russian).

World Bank (2004). From Transition to Development: A Country Economic Memorandum for the Russian Federation, World Bank: Moscow.

World Bank (2005a). Where Is the Wealth of Nations? Measuring Capital for the XXI Century, World Bank: Washington DC.

World Bank (2005b). Growth, Poverty, and Inequality: Eastern Europe and the Former Soviet Union, World Bank: Washington DC. 
World Bank (2006). Azerbaijan Extended Poverty Profile 2002-2004, World Bank: Washington DC.

World Wealth Report (various). Capgemini and Merrill Lynch: New York

Yemtsov, R. (2006). 'Housing Privatization and Household Wealth in Transition', mimeo, World Bank: Washington DC.

\section{Appendix}

Table A1: Monetization M2/GDP in transition countries and in the US

\begin{tabular}{|c|c|c|c|c|}
\hline & 1994 & 1997 & 2000 & 2003 \\
\hline Czech Republic & 65 & 65 & 63 & 70 \\
\hline Croatia & 16 & 35 & 42 & 63 \\
\hline Slovak Republic & 56 & 60 & 60 & 61 \\
\hline Albania & .. & 55 & 59 & 58 \\
\hline Slovenia & 29 & 39 & 44 & 53 \\
\hline Bosnia and Herzegovina & .. & .. & 26 & 47 \\
\hline Hungary & 48 & 43 & 43 & 45 \\
\hline Bulgaria & 62 & 21 & 33 & 45 \\
\hline Poland & 30 & 31 & 39 & 42 \\
\hline Estonia & 24 & 26 & 32 & 38 \\
\hline Latvia & 29 & 22 & 25 & 33 \\
\hline Ukraine & 15 & 12 & 16 & 30 \\
\hline Macedonia, FYR & 21 & 12 & 18 & 30 \\
\hline Lithuania & 21 & 16 & 21 & 29 \\
\hline Moldova & 12 & 19 & 19 & 28 \\
\hline Russian Federation & 14 & 18 & 18 & 26 \\
\hline Romania & 15 & 18 & 20 & 22 \\
\hline Kazakhstan & 8 & 9 & 13 & 19 \\
\hline Kyrgyz Republic & .. & 12 & 11 & 15 \\
\hline Belarus & .. & 12 & 12 & 14 \\
\hline Armenia & 7 & 8 & 13 & 14 \\
\hline Turkmenistan & 14 & 8 & 14 &.. \\
\hline Azerbaijan & 30 & 12 & 13 & 13 \\
\hline Georgia & .. & 7 & 9 & 11 \\
\hline Tajikistan & .. & .. & 7 & 7 \\
\hline USA & 57 & 56 & 61 & 67 \\
\hline
\end{tabular}

Source: World Bank's World Development Indicators. 
Figure A1: The ratio of stock market capitalization to GDP

Market capitalization of listed companies ( $\%$ of GDP)

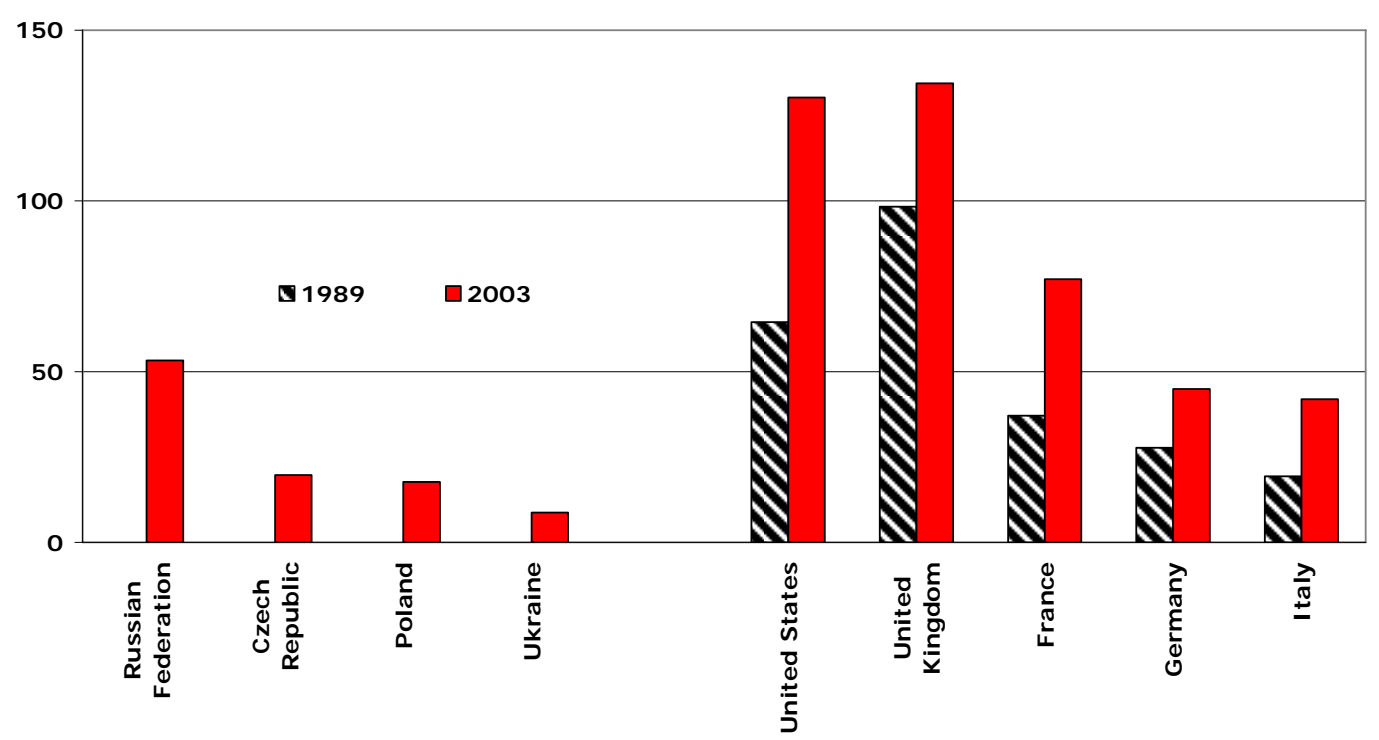

Source: World Bank's World Development Indicators. 